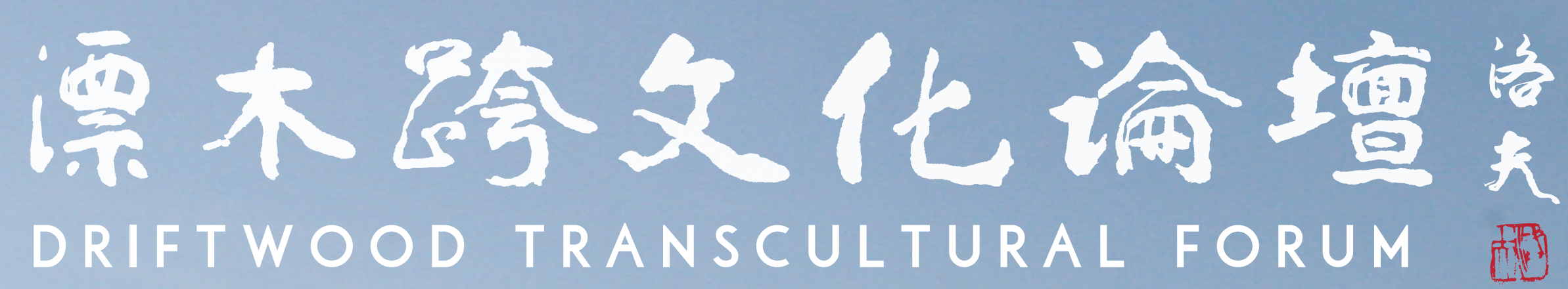

Engaging with Lo Fu's unique aesthetics of exile and his concerns for displacement and drifting as the everlasting fate of humanity, the forum aims at establishing an annual international platform to facilitate transcultural debate, discussion and dialogue.

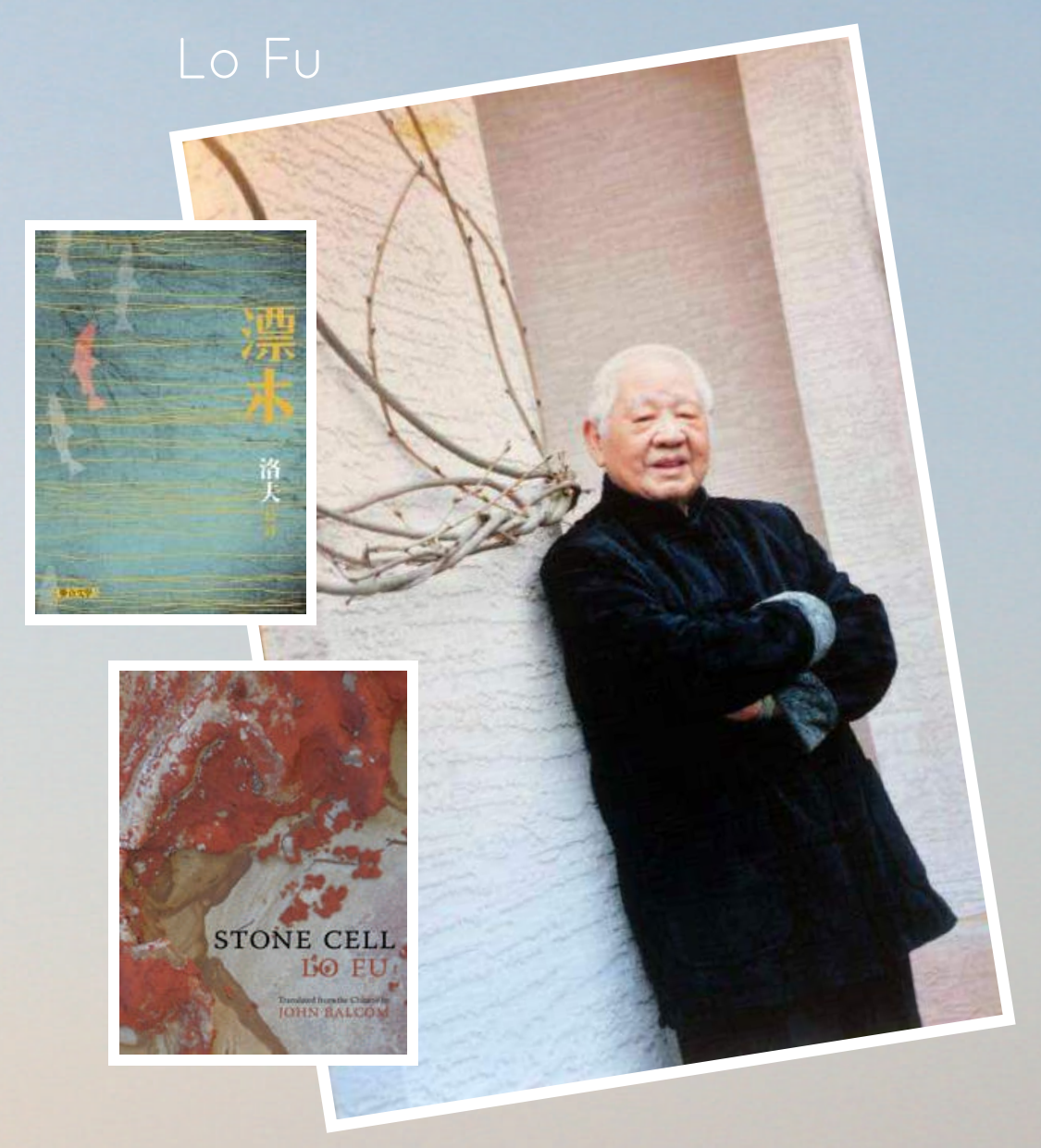

Actually for us salmon
A hundred years
Is but the span of a fishbone

After fish scales, bellies, fins, and bones Are cut away our silence will grow Ours, the same lame history as yours

其实，对我们这群红鲑来说

百年之间

只横梗着一根鱼刺

至于鱼鳞，鱼肚，鱼鿷，鱼骨头

拆散之后我们就更为沉默

和你们一样有着麻痹的历史

LIST OF SCHOLARS AND HONOURED GUESTS:

Tsui-Ying Lee

nominee, and Chairman of Driftwood Artists Association

Associate Professor, Department of Chinese Linguistics and -

John Balcom

Laifong Leung

and the English translater of Lo Fu's twa volumes of poetry

Jianchun Chen

Chinese-Canadian Writer's Association

Sunera Thobani

Associate Professor, Institute for Gender, Race, Sexuality and Social

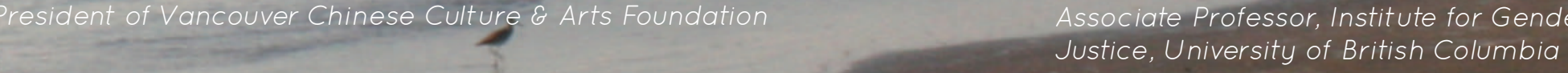

Ronghua Chen

Initiator of Driftwood Culture Fund, Executive Vice President of

\title{
Jan Walls
}

Professor Emeritus, Founding Director of David See-chai Lam Centre for International Communication at SFU

Bronwyn Drainie
Former Editor-in-Chief, Literary Review of Canada

\section{Xiong Gu}

Professor, Department of Art History, Visual Art \& Theory, University,

of British Columbia

Richard King

Professor, Pacific and Asian Studies, University of Victoria

AUGUST 6, 2016 (9:00 AM - 8:00 PM) JOSEPH \& ROSALIE SEGAL CENTRE (1400-1410), HARBOUR CENTRE, 515 W HASTINGS ST, VANCOUVER

\section{Yuezhi Zhao}

Canada Research Chair in Political Economy of Global

Communication, School of Communication, Simon Fraser University

\section{Yueping Zhou}

Secretary-General of China Art Fortune Forum

\begin{tabular}{l|l|l} 
Sponsored By & $\begin{array}{l}\text { Vancouver Chinese } \\
\text { Culture \& Arts } \\
\text { Foundation }\end{array}$ & $\begin{array}{l}\text { David Lam Centre for } \\
\text { International } \\
\text { Communication at SFU }\end{array}$
\end{tabular}

Faculty of

Communication, Art and Technology at SFU
M.A. Double Degree

Program in Global

Communication at SFU
MEDIA SUPPORT

Orient Star Media
RELATED EVENTS

Lo Fu's Calligraphy Exhibition

by Driftwood Artists Association

7 p.m. August 6, Jewish Community Centre

950 W 41 st Ave, Vancouver

by Vancouver International Arts Gallery

2 p.m. August 7, International Village Mall.

$88 \mathrm{~W}$ Pender Street, Vancouver 